УДК 550.461

\title{
ОСОБЕННОСТИ ПОВЕДЕНИЯ ХИМИЧЕСКИХ ЭЛЕМЕНТОВ В СИСТЕМЕ ВОДА-ПОРОДА РАЙОНА РАЗРАБАТЫВАЕМОГО КАРЬЕРА БУТОВОГО КАМНЯ В ПИТКЯРАНТСКОМ РУДНОМ РАЙОНЕ (КАРЕЛИЯ)
}

\author{
Конышев Артем Александрович 1 , \\ icelopa@gmail.com
}

\author{
Сидкина Евгения Сергеевна ${ }^{1}$, \\ sidkinaes@yandex.ru
}

\section{Солдатова Евгения Александровна 1 , 2a61@mail.ru}

\section{Догадкин Денис Николаевич1, denisnd@mail.ru}

\author{
Громяк Ирина Николаевна', \\ gnom.motl@bk.ru \\ 1 Институт геохимии и аналитической химии им. В.И. Вернадского РАН, \\ Россия, 119991, г. Москва, ул. Косыгина, 19.
}

\begin{abstract}
Актуальность. Изучение особенностей перераспределения химических элементов в системе вода-порода в районах, где ведется активная разработка месторождений полезных ископаемых, актуально ввиду потенциального влияния этих процессов на экологическую обстановку и изменение геохимических условий природной среды. В частности, это важно для выбранного района, который входит в площадь водосбора крупнейшего природного резервуара пресной воды в Европе - Ладожского озера. Целью представленного исследования является изучение выноса химических элементов водой из гранитоидных пород, вскрытых карьером, и их дальнейшего поведения в природных водах и донных отложениях района.
\end{abstract}

Объектом исследования являются природные воды и донные отложения района разрабатываемого карьера бутового камня (Питкярантский рудный район, республика Карелия). Авторы проследили изменения химического состава природных вод и связанных с ними донных отложений по мере движения воды от ее сброса из карьера до впадения в речную сеть.

Методы. Анализ химического состава природных вод и донных отложений проведен стандартными методами: потенциометрия, титриметрия, ICP-AES, ICP-MS. Исследования минералов в составе пород карьера бутового камня проведено при помощи LA-ICP-MS, химический состав горных пород изучен методами XRF, ICP-MS и ICP-AES. Физико-химическое моделирование форм нахождения в природных водах и осаждения минералов проведено в программном комплексе HydroGeo. Bepuфрикаиия модели проведена на основе анализа химического состава донных отложений.

Результаты. В изученных водных объектах в отдельных точках отмечены превышения ПДК Fe, Mn, Cu, Zn, Mo, V. При удалении от карьера бутового камня снижается величина общей минерализации природных вод и содержание макрокомпонетов, а также Sr, U, V, Mo, Zn, Cd. Концентрация железа, наоборот, увеличивается ввиду роста содержания органического вещества в воде. В донных отложениях пик концентрации многих элементов ( $\mathrm{Fe}, \mathrm{Mn}, \mathrm{Co}, \mathrm{Cu}, \mathrm{Zn}, \mathrm{Cs}, \mathrm{Ce}, \mathrm{La}, \mathrm{Y})$ наблюдается в точке сброса воды из карьера. Максимальное содержание U отмечается чуть ниже по потоку изучаемьхх вод, что согласуется $c$ данными по составу донных отложений и моделирования, которые указывают на возможность выпадения уранинита из водного раствора в водоеме, сформировавшемся при сбросе воды из карьера бутового камня и истоке ручья, берущего начало в этом водоеме. Роль органического вещества в изученных водах высока для процесса накопления железа в воде за счет образования устойчивого гидроксо-фрульватного комплекса железа, а также для редкоземельных элементов за счет образования комплекса с гуминовой кислотой. Анализ распространенности, форм нахождения и осаждения химических элементов позволили заключить, что эксплуатация карьера бутового камня вносит существенный вклад в перераспределение химических элементов в изучаемом районе.

\section{Ключевые слова:}

Система вода-порода, выщелачивание, формы нахождения, осаждение, фрульвокислота, гуминовая кислота, растворенное органическое вещество, термодинамический расчет, уран, комплексообразование.

\section{Введение}

Особенности перераспределения химических элементов между породами и природными водными растворами в рудных районах, где ведется активная разработка месторождений полезных ископаемых, представляют значительный интерес для изучения ввиду потенциального влияния этих процессов на экологическую обстановку и изменение геохимических усло- вий природной среды [1-3]. Изучаемая территория располагается в пределах Питкярантского рудного района в юго-западной части Республики Карелия, вдоль северо-восточного побережья Ладожского озеpa (рис. 1). В Питкярантском рудном районе открыты многочисленные месторождения и рудопроявления олова, железа, редких и полиметаллов, флюорита, урана и др. $[4,5]$. Все рудные объекты приурочены к полосе, протягивающейся вдоль северо-западного 
контакта Салминского батолита более чем на 50 км [4]. Многие месторождения известны с XVIII в. с пиком их эксплуатации в XIX в. [5]. Из нерудных полезных ископаемых в исследуемом районе в XX в. разрабатывались пегматиты на керамическое сырье, в настоящее время ведется добыча строительных материалов. В перечень ценных природных ресурсов помимо вышеперечисленных необходимо включить природные воды, которыми исключительно богат регион. Следует отметить, что в природных водах района исследований отмечаются повышенные концентрации ряда микрокомпонентов в результате влияния природных (взаимодействие с породами) и техноген- ных (в основном разработка полезных ископаемых) факторов. Район исследований входит в площадь водосбора крупнейшего природного резервуара пресной воды в Европе - Ладожского озера. В связи с этим изучение особенностей взаимодействий в системе вода-порода в связи с их влиянием на формирование химического состава природных вод выбранной территории является весьма актуальной проблемой. Задачей представленного исследования является изучение выноса химических элементов водой из гранитоидных пород, вскрытых карьером бутового камня, и их дальнейшего поведения в природных водах и донных отложениях района.

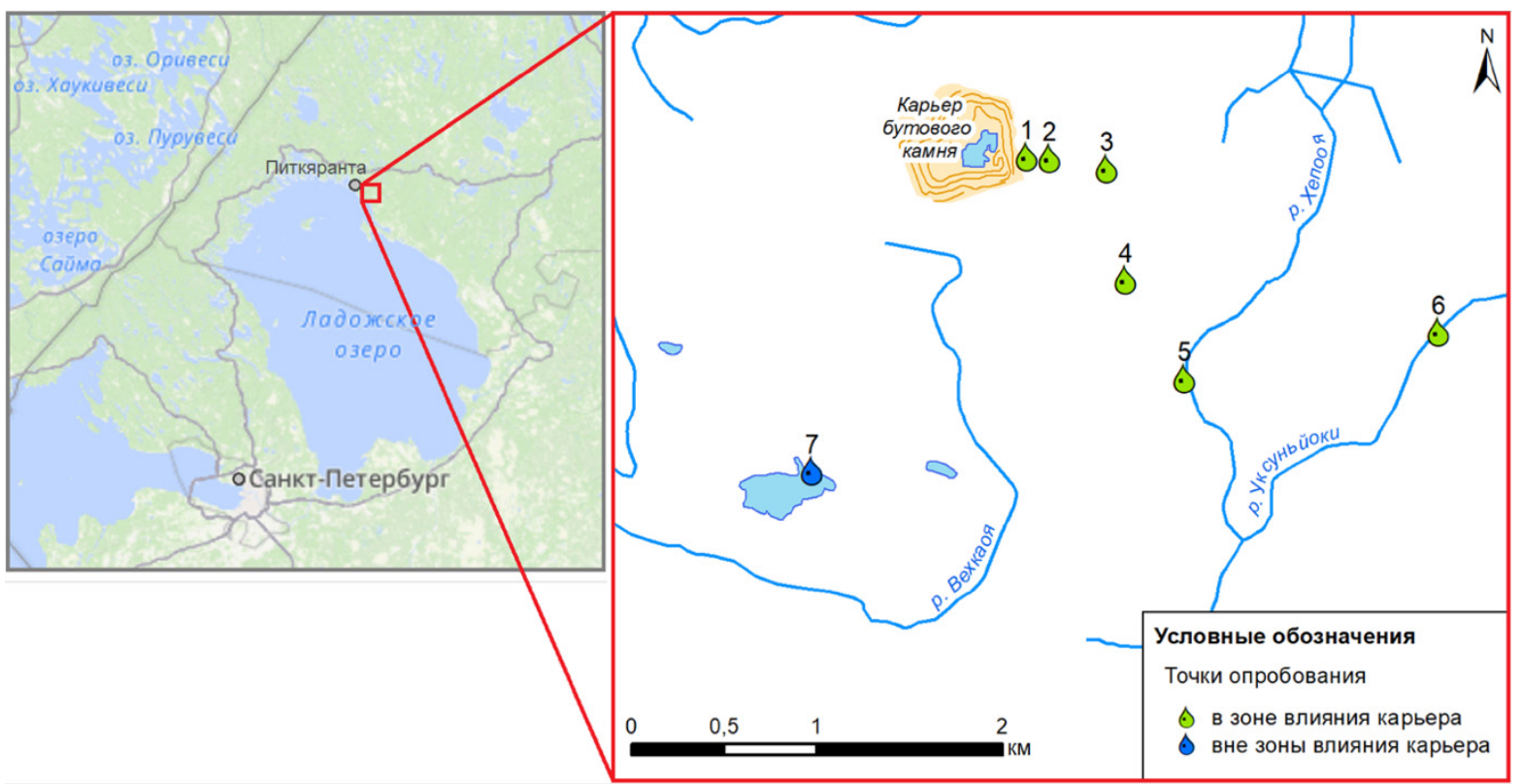

Pис. 1. Карта района работ с нанесением точек опробования: 1 - водоем, сформированный в результате сброса воды из карьера бутового камня; 2 - исток ручья, сформированного водой, откачиваемой из карьера; 3 тот же ручей, ниже по течению; 4 - заболоченная местность; 5 - p. Хепооя после впадения исследуемого ручья, 6-p. Уксуньйоки, 7-пегматитовый карьер

Fig. 1. Map of the study area with location of the sampling points: 1 - waterbody formed due to water discharge from the rubble stone quarry; 2 - head of the stream formed by water discharged from the quarry; 3 - the same stream, downstream; 4 -wetland; 5 - Hepooya River after the stream influx; 6-Uuksunjoki River; 7 -pegmatite quarry

\section{Геологическая характеристика района и объекта исследований}

Тектонические особенности

Салминский батолит расположен в РаaхеЛадожской зоне - месте сочленения крупных геоблоков, Свекофеннской складчатой области и Карельского кратона. В геологическом плане Питкярантский рудный район приурочен к Карельской зоне Свекофеннской складчатой области. Данный район представляет собой область распространения метаосадочных пород верхнего протерозоя, в том числе карбонатных и ремобилизованных при сфекофеннской орогении гнейсогранитных куполов $\mathrm{AR}_{2}-\mathrm{PR}_{1}$ возраста. Интрузивные породы Салминского батолита в данном месте полого погружаются под метаосадочный чехол в направлении Ладожского озера с резким изменением наклона на субвертикальный вблизи его береговой линии. Мощность пород Салминского батолита в изучаемом районе составляет 2-3 км [6].
На изучаемой территории, а также в пределах котловины Ладожского озера существуют тектонические нарушения северо-западного простирания, субпараллельные зоне сочленения Свекофеннской складчатой области с Карельским кратоном. Часть из этих разломов испытывала активацию в верхнем протерозое, сформировав Ладожско-Пашскую грабен-синклиналь.

Таким образом, Питкярантский рудный район расположен вблизи основных региональных разломов, в том числе глубокого заложения, и вытянут параллельно им, а также приурочен к зоне резкого перегиба наклона кровли Салминского батолита.

\section{Описание карьера бутового камня}

Карьер бутового камня, из которого происходит сброс воды, разрабатывается свыше 50 лет, имеет 5 уступов и размеры около $550 \times 600$ м. Карьером вскрываются: четвертичные песчаные отложения, гнейсограниты купола Люпикко $\left(\mathrm{AR}_{2}-\mathrm{PR}_{1}\right)$ с входя- 
щими в них метаамфиболитами, высокодифференцированные топазсодержащие Li-сидерофиллитовые граниты [7] или альбит-протолитионитовые граниты

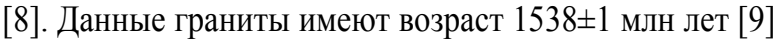
и являются частью Салминского батолита. Апикаль- ная часть батолита, непосредственно под гнейсогранитным куполом Люпикко, представлена высокодифференцированными разностями, основной объём на глубине сложен биотит-амфиболовыми гранитами [8] (рис. 2).
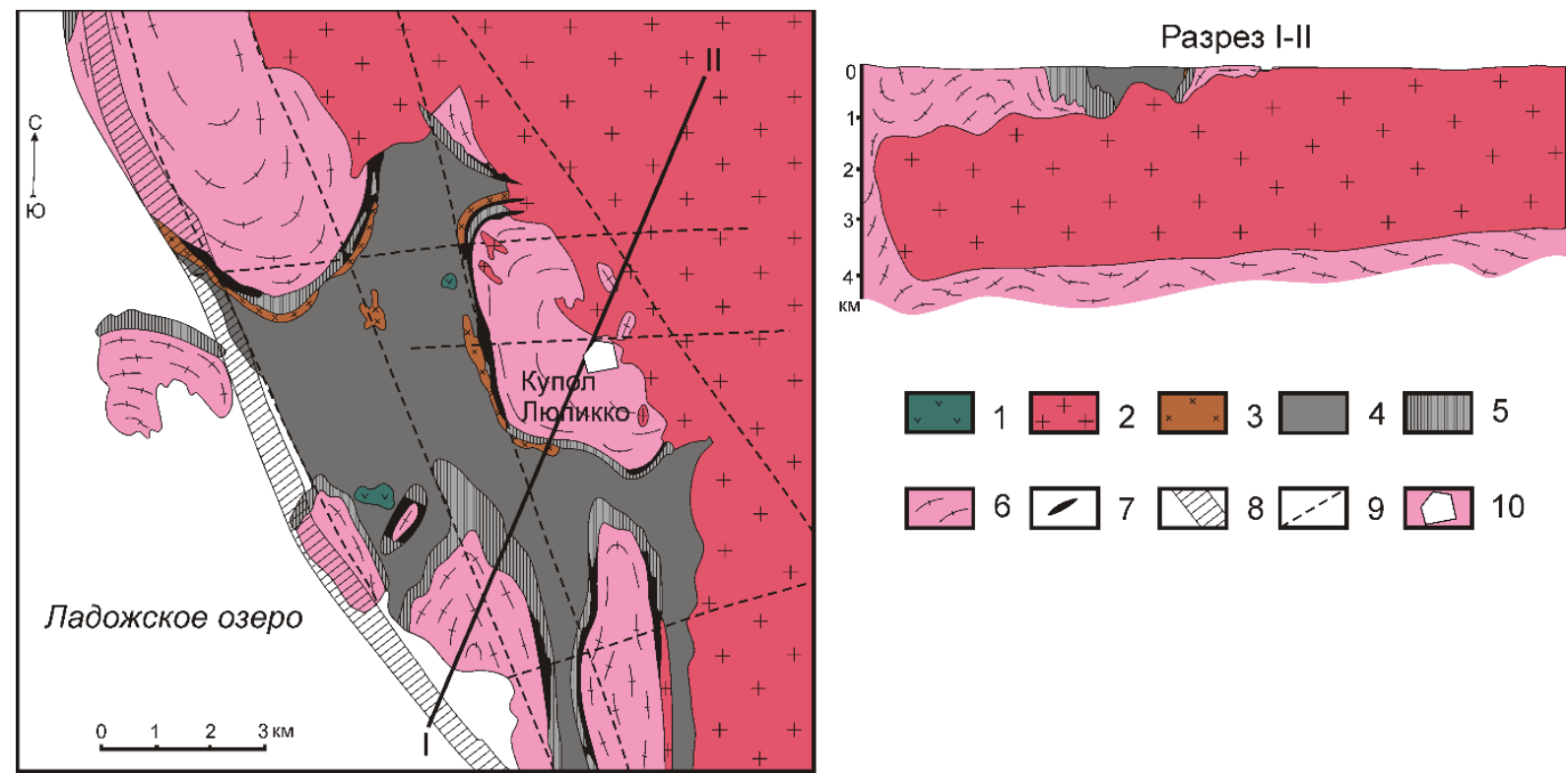

Pис. 2. Геологическая схема Питкярантского рудного района по [8] с упрощениями и дополнениями. Условные обозначения: 1 - интрузивные породы Йотния; 2 - гранитные породы Салминского батолита; 3-6 - Свекофеннский комплекс: 3 - керамические пегматиты, 4 - богатые алюминием сланцы Ладожской серии, 5 амфиболиты и амфиболовые сланщы с карбонатными горизонтами (Сортавальская серия), 6 - гранитогнейсы куполов; 7 - Sn-полиметаллические и Be-Sn-полиметаллические месторождения и рудопроявления; 8 - проекиия резкого изгиба наклона кровли Салминского батолита на современную поверхность в месте смены пологого наклона на субвертикальный; 9 - разрывные нарушения; 10 - карьер бутового камня

Fig. 2. Geological scheme of Pitkyaranta district according to [8] with simplifications and additions. Legend: 1 - Jotnian intrusive rocks; 2 - granite rocks of the Salmi batholith; 3-6-Svecofennian complex: 3 - «ceramic» pegmatites, 4 Al-enriched schists of Ladoga group, 5 - amphibolites and amphibole schists with carbonate horizons (Sortavala group), 6-gneiss-granites of domes; 7 -Sn-polymetallic and Be-Sn-polymetallic mineral deposits and ore occurrences; 8 - projection of a sharp bend of the overlying bed slope of the Salmi batholith onto the modern surface at the place of the gentle slope change to the subvertical slope; 9 -disjunctive dislocations; 10 - the rubble stone quarry

Кровля кристаллических пород сильно эродирована, в северной стенке карьера наблюдаются отложения песков четвертичного возраста мощностью до 10-15 м. Восточная стенка карьера сложена высокодифференцированными гранитами, кровля которых срезается эрозией. На расстоянии до первых десятков метров вблизи карьера наблюдается сухостой и деградация кустарникового покрова. Вода в карьер просачивается из стенок и скапливается на дне, где имеет голубовато-зеленоватый цвет.

\section{Методы проведения исследования}

Отбор проб и аналитические методы исследования вещества

В ходе полевых работ 2019 г. были отобраны 7 проб воды и 6 проб донных отложений. Схема пробоотбора приведена на рис. 1. Точка 1 представляет собой водоём, сформированный в результате сброса воды из карьера бутового камня. Материал донных отложений в этой точке представлен крупнозернистым песком с примесью глинистого материала. Из водоёма вытекает ручей, который после перепада вы- сот порядка 15 м попадает на заболоченную равнину. Интенсивность заболоченности меняется в зависимости от объема поверхностного стока и количества атмосферных осадков. Точка 2 - исток упомянутого ручья, который в непосредственной близости от точки 1 имеет временный характер, местами течения на поверхности не наблюдается, но русло прослеживается. Донные отложения в точке 2 представлены органическими остатками преимущественно растительного происхождения с незначительной примесью песчаного материала. Точка 3 - тот же ручей ниже по течению, где он приобретает постоянный характер. Материал донных отложений также представляет собой органические остатки с примесью песчаного материала. Точка 4 - заболоченная равнина ниже по течению ручья, где он разветвляется на рукава. Отбор пробы произведен из рукава ручья. Материал донных отложений - органические остатки с незначительной примесью песчаного материала. Точка 5 - р. Хепооя, проба взята в 50 м ниже по течению от места впадения ручья. В этом месте р. Хепооя имеет ширину до 1-1,5 м, донные отложения представлены преимуще- 
ственно песчаным материалом. Точка 6 - р. Уксуньйоки. В месте пробоотбора река имеет ширину около 20 м. Донные отложения представлены смесью песчаного материала и органического вещества. Точка 7 - затопленный пегматитовый карьер (на керамическое сырье), проба отобрана непосредственно из карьера. Пегматитовый карьер находится в районе исследований, но гидрографически не связан с изучаемой нами системой поверхностных вод. Эта точка будет использована в работе как точка сравнения.

Для анализа макрокомпонентов пробы природных вод были отобраны в пластиковые бутылки объемом 1 литр с предварительным многократным ополаскиванием тары природной водой. При пробоотборе анализировались $\mathrm{pH}, \mathrm{Eh}, \mathrm{CO}_{3}{ }^{2-}$ потенциометрическим методом ионоселективными электродами при помощи прибора ЭКОТЕСТ 2000 (ЭКОНИКС, Россия) Пробы были доставлены в лабораторию в течение трех дней после пробоотбора и от момента отбора до химического анализа хранились в темном месте. Анализ макрокомпонентов был выполнен в МГУ им. М.В. Ломоносова методом титрования. Перманганатная окисляемость была измерена методом титрования в ГЕОХИ РАН. Пересчет данных по перманганатной окисляемости в содержания гуминовых и фульвокислот произведен согласно [10].

Пробы для анализа микроэлементов были отобраны в пробирки объемом 15 мл с консервацией 0,45 мл $\mathrm{HNO}_{3}$ ос. ч. и отфильтрованы при помощи ацетатцеллюлозного мембранного фильтра с размером пор 0,45 мкм. Элементный анализ воды был выполнен в ГЕОХИ РАН: Fe, Al, Na, K определяли методом ICPAES (плазменный спектрометр iCAP 6500 DUO (Thermo Scientific)). Содержания $\mathrm{Mn}, \mathrm{Cu}, \mathrm{Zn}, \mathrm{Mo}, \mathrm{U}$ и других микроэлементов определены методом ICP-MS на квадрупольном масспектрометре X-series 2 (Thermo Scientific).

Отбор проб органоминеральных отложений произведен в герметичные полиэтиленовые пакеты при помощи пластикового совка с заглублением не более 15 см. Масса каждой пробы составляла около 1 кг. В лаборатории грунты были высушены, просеяны через сито с размером ячеек 1 мм. Пробы проанализированы в ГЕОХИ РАН методами ICP-AES и ICP-MS на тот же перечень химических элементов, что и пробы воды. Определение зольности грунта проведено по методике определения сборной пробы по ГОСТ 26801-86 в муфельной печи. Пробы грунтов после прокаливания приобрели светлый оттенок и были представлены песчаным материалом. Вычисление массовой доли органического вещества произведено по формуле:

$$
0=100-A_{d},
$$

где $A_{\mathrm{d}}$ - массовая доля золы, \%

Исследования содержания урана в минералах в составе пород карьера бутового камня проведено при помощи LA-ICP-MS на масc-спектрометре Element $\mathrm{XR}$ с системой лазерного пробоотбора UP-213 в ГЕОХИ РАН.
Термодинамический расчет форм нахождения химических элементов и осаждения минералов из водного раствора

Термодинамические расчеты проведены с помощью программного комплекса HydroGeo [11]. Система состояла из 24 химических элементов: $\mathrm{O}, \mathrm{H}, \mathrm{C}, \mathrm{S}, \mathrm{Cl}, \mathrm{Ca}$, $\mathrm{Mg}, \mathrm{Na}, \mathrm{K}, \mathrm{Fe}, \mathrm{Al}, \mathrm{Mn}, \mathrm{Co}, \mathrm{Ni}, \mathrm{Cu}, \mathrm{Zn}, \mathrm{Cd}, \mathrm{Sr}, \mathrm{Y}, \mathrm{Ce}, \mathrm{La}$, $\mathrm{U}, \mathrm{Fu}$ (фульвокислота), Нu (гуминовая кислота).

Для расчета свободных энергий образования комплексов с фульвовыми и гуминовыми кислотами были использованы эффективные константы устойчивости, приведенные в табл. 1. Свободные энергии $\mathrm{Fu}^{2-}$ и $\mathrm{Hu}^{-}$приняты равными нулю, а сами $\mathrm{Fu}$ и Нu введены в базу данных как новые независимые элементы.

Таблица 1. Эффективные константы комплексообразования катионов с гуминовыми и фульвокислотами (298,15 K, 1 бар), использованные при расчетах

Table 1. Effective constants of cation complexation with humic and fulvic acids $(298,15 \mathrm{~K}, 1 \mathrm{bar})$ used in calculations

\begin{tabular}{|c|c|c|}
\hline $\begin{array}{l}\text { Комплексная частица } \\
\text { Complex }\end{array}$ & $\mathrm{pK}$ & $\begin{array}{l}\text { Литературный источник } \\
\text { Reference }\end{array}$ \\
\hline $\mathrm{CaFu}^{0}$ & 3,64 & {$[12]$} \\
\hline $\mathrm{CaHu}^{+}$ & 3,83 & {$[13,14]$} \\
\hline $\mathrm{MgFu}^{0}$ & 3,81 & {$[14]$} \\
\hline $\mathrm{MgHu}^{+}$ & 3,67 & {$[13,14]$} \\
\hline $\mathrm{MnFu}^{0}$ & 4,17 & {$[14]$} \\
\hline $\mathrm{MnHu}^{+}$ & 4,58 & {$[14,15]$} \\
\hline $\mathrm{FeFu}^{0}$ & 4,67 & {$[12]$} \\
\hline $\mathrm{FeFu}^{+}$ & 7 & [16] \\
\hline $\mathrm{FeOHFu}^{0}$ & 19,5 & [13] \\
\hline $\mathrm{Fe}(\mathrm{OH})_{2} \mathrm{Fu}^{-}$ & 29,41 & [13] \\
\hline $\mathrm{Fe}(\mathrm{Hu})_{3}{ }^{0}$ & 10,52 & [17] \\
\hline $\mathrm{AlFu}^{+}$ & 6,46 & {$[18]$} \\
\hline $\mathrm{CoFu}^{0}$ & 4,51 & {$[13,14]$} \\
\hline $\mathrm{Co}(\mathrm{Hu})_{2}{ }^{0}$ & 5,44 & [17] \\
\hline $\mathrm{CuFu}^{\circ}$ & 7,85 & [14] \\
\hline $\mathrm{Cu}(\mathrm{OH})_{2} \mathrm{Fu}^{2-}$ & 7,74 & [19] \\
\hline $\mathrm{CuHu}^{+}$ & 6,2 & [20] \\
\hline $\mathrm{Cu}(\mathrm{Hu})_{2}{ }^{0}$ & 8,9 & [21] \\
\hline $\mathrm{NiFu}^{0}$ & 4,98 & {$[13,14]$} \\
\hline $\mathrm{NiHu}^{+}$ & 3,67 & {$[13]$} \\
\hline $\mathrm{ZnFu}^{0}$ & 4,83 & {$[14]$} \\
\hline $\mathrm{ZnHu}^{+}$ & 5,19 & {$[14,15]$} \\
\hline $\mathrm{CdFu}^{0}$ & 4,57 & {$[14]$} \\
\hline $\mathrm{CdHu}^{+}$ & 5,04 & [20] \\
\hline $\mathrm{Cd}(\mathrm{Hu})_{2}{ }^{0}$ & 6,9 & [21] \\
\hline $\mathrm{SrFu}^{0}$ & 3,57 & [22] \\
\hline $\mathrm{SrHu}^{+}$ & 2,64 & [23] \\
\hline $\mathrm{Sr}(\mathrm{Hu})_{2}{ }^{0}$ & 4,68 & [23] \\
\hline $\mathrm{UO}_{2} \mathrm{Fu}^{0}$ & 4,54 & [24] \\
\hline $\mathrm{UO}_{2}(\mathrm{Fu})_{2}{ }^{2-}$ & 7,45 & [24] \\
\hline $\mathrm{UO}_{2} \mathrm{Hu}^{+}$ & 5,38 & [24] \\
\hline $\mathrm{UO}_{2}(\mathrm{Hu})_{2}{ }^{0}$ & 9,59 & [24] \\
\hline $\mathrm{LaFu}^{+}$ & 9,15 & [25] \\
\hline $\mathrm{LaHu}^{2+}$ & 10,64 & [25] \\
\hline $\mathrm{CeFu}^{+}$ & 6,75 & [25] \\
\hline $\mathrm{CeHu}^{2+}$ & 5,75 & [25] \\
\hline $\mathrm{YFu}^{+}$ & 9,21 & [25] \\
\hline $\mathrm{YHu}^{2+}$ & 10,95 & {$[25]$} \\
\hline
\end{tabular}

Добавленные в базу термодинамических данных HydroGeo свободные энергии образования фульватных и гуматных комплексов химических элементов рассчитаны по уравнению:

$$
G_{f M e A}^{0 *}=G_{f M e^{m+}}^{0}-R T \ln K_{\ni \phi},
$$


где $G_{f M e A}^{0 *}$ - свободная энергия образования комплекca с органическим анионом; $G_{f M e^{m+}}^{0}-$ свободная энергия иона металла; $R$ - газовая постоянная; $T$ температура $(298,15 \mathrm{~K}) ; K_{э \phi}-$ эффективная константа устойчивости [10].
В качестве потенциально возможных твердых фаз были приняты: магнезит, кальцит, доломит, сидерит, $\mathrm{Fe}(\mathrm{OH})_{3}$, гетит, тенорит, смитсонит, цинкит, брусит, гиббсит, уранинит, гуммит. Список компонентов водного раствора, рассматриваемый в модели, приведен в табл. 2.

Таблица 2. Ионы и комплексные частицы, добавленные в модель

Table 2. Ions and complexes incorporated to the numerical model

\begin{tabular}{|c|c|c|c|c|c|c|c|}
\hline $\begin{array}{c}\mathrm{H}^{+} \\
\mathrm{OH}^{-} \\
\mathrm{H}_{2} \mathrm{O} \\
\mathrm{HCO}_{3}{ }^{-} \\
\mathrm{CO}_{3}{ }^{2-} \\
\mathrm{CO}_{2}{ }^{0} \\
\mathrm{SO}_{4}{ }^{2-} \\
\mathrm{Fu}^{2-} \\
\mathrm{HFu}^{-} \\
\mathrm{H}_{2} \mathrm{Fu}^{0} \\
\mathrm{Hu}^{-} \\
\mathrm{HHu}^{0} \\
\mathrm{Cl}^{-} \\
\mathrm{Na}^{+} \\
\mathrm{NaHCO}_{3}{ }^{0}\end{array}$ & $\begin{array}{c}\mathrm{NaSO}_{4}^{-} \\
\mathrm{K}^{+} \\
\mathrm{KHCO}_{3}{ }^{0} \\
\mathrm{KSO}_{4}{ }^{-} \\
\mathrm{Mg}^{2+} \\
\mathrm{MgHCO}_{3}^{+} \\
\mathrm{MgSO}_{4}{ }^{+} \\
\mathrm{MgFu}^{0} \\
\mathrm{MgHu}^{+} \\
\mathrm{Ca}^{2+} \\
\mathrm{CaHCO}_{3}{ }^{+} \\
\mathrm{CaCO}_{3}{ }^{0} \\
\mathrm{CaSO}_{4}{ }^{0} \\
\mathrm{CaFu}^{0} \\
\mathrm{CaHu}^{+} \\
\end{array}$ & $\begin{array}{c}\mathrm{Fe}^{3+} \\
(\mathrm{FeHCO} 3)^{+} \\
\left(\mathrm{Fe}(\mathrm{OH})_{2} \mathrm{Fu}\right)^{-} \\
\mathrm{FeOHFu}{ }^{0} \\
\mathrm{FeHu}{ }^{0} \\
\mathrm{Fe}(\mathrm{OH})_{3}{ }^{0} \\
\mathrm{Mn}^{3+} \\
\mathrm{MnHCO}_{3}{ }^{+} \\
\mathrm{MnSO}_{4}{ }^{0} \\
\mathrm{Mn}^{2+} \\
\mathrm{MnFu}^{0} \\
\mathrm{MnHu}^{+} \\
\mathrm{Al}^{3+} \\
\mathrm{Al}_{2}\left(\mathrm{CO}_{3}\right)_{3}{ }^{0} \\
\mathrm{AlSO}_{4}{ }^{+} \\
\end{array}$ & $\begin{array}{c}\mathrm{AlFu}^{+} \\
\mathrm{Al}(\mathrm{OH})_{3} \\
\mathrm{Al}(\mathrm{OH})_{2}{ }^{+} \\
\mathrm{Ni}^{2+} \\
\mathrm{NiHCO}_{3}{ }^{+} \\
\mathrm{NiFu}^{0} \\
\mathrm{NiOH}^{+} \\
\mathrm{Ni}(\mathrm{OH})_{2}{ }^{0} \\
\mathrm{Cu}^{2+} \\
\mathrm{CuHCO}_{3}{ }^{+} \\
\mathrm{CuSO}_{4}{ }^{0} \\
\mathrm{CuCl}^{+} \\
\mathrm{Cu}^{+} \\
\mathrm{CuFu}^{0} \\
\mathrm{Cu}(\mathrm{OH})_{2} \mathrm{Fu}^{2-}\end{array}$ & $\begin{array}{c}\mathrm{CuHu}_{2}{ }^{0} \\
\mathrm{CuHu}^{+} \\
\mathrm{CuOH}^{+} \\
\mathrm{Zn}^{2+} \\
\mathrm{ZnHCO}_{3}{ }^{+} \\
\mathrm{ZnSO}_{4}{ }^{0} \\
\mathrm{ZnFu}^{0} \\
\mathrm{ZnHu}^{+} \\
\mathrm{Cd}^{2+} \\
\mathrm{CdHCO}_{3}{ }^{+} \\
\mathrm{CdSO}_{4}{ }^{0} \\
\mathrm{CdFu}^{0} \\
\mathrm{CdHu}^{+} \\
\mathrm{CdHu}_{2}{ }^{0} \\
\mathrm{Co}^{3+} \\
\end{array}$ & $\begin{array}{c}\mathrm{CoHCO}_{3}^{+} \\
\mathrm{CoSO}_{4}{ }^{0} \\
\mathrm{Co}^{2+} \\
\mathrm{CoFu}^{0} \\
\mathrm{CoHu}_{2}{ }^{0} \\
\mathrm{Sr}^{2+} \\
\mathrm{SrHCO}_{3}{ }^{+} \\
\mathrm{SrSO}_{4}{ }^{0} \\
\mathrm{SrFu}^{0} \\
\mathrm{SrHu}_{2}{ }^{0} \\
\mathrm{SrHu}^{+} \\
\mathrm{Y}^{3+} \\
\mathrm{YFu}^{+} \\
\mathrm{YHu}^{2+} \\
\mathrm{YOH}^{2+} \\
\end{array}$ & $\begin{array}{c}\mathrm{Ce}^{3+} \\
\mathrm{CeHCO}_{3}{ }^{2+} \\
\mathrm{CeSO}_{4}{ }^{+} \\
\mathrm{CeFu}^{+} \\
\mathrm{CeHu}^{2+} \\
\mathrm{CeOH}^{2+} \\
\mathrm{La}^{3+} \\
\mathrm{LaHCO}_{3}{ }^{2+} \\
\mathrm{LaSO}_{4}{ }^{+} \\
\mathrm{LaFu}^{+} \\
\mathrm{LaHu}^{2+} \\
\mathrm{LaOH}^{2+} \\
\mathrm{UO}_{2}{ }^{2+} \\
\mathrm{UO}_{2} \mathrm{HCO}_{3}{ }^{+} \\
\mathrm{UO}_{2}\left(\mathrm{HCO}_{3}\right)_{2}{ }^{0}\end{array}$ & $\begin{array}{c}\mathrm{UO}_{2} \mathrm{CO}_{3}{ }^{0} \\
\mathrm{UO}_{2}\left(\mathrm{CO}_{3}\right)_{2}{ }^{2-} \\
\mathrm{UO}_{2}\left(\mathrm{CO}_{3}\right)_{3}{ }^{4} \\
\mathrm{UO}_{2}\left(\mathrm{CO}_{3}\right)_{3}{ }^{5-} \\
\mathrm{UO}_{2} \mathrm{SO}_{4}{ }^{0} \\
\mathrm{UO}_{3}{ }^{0} \\
\mathrm{UO}_{2} \mathrm{OH}^{+} \\
\mathrm{UO}_{2}(\mathrm{OH})_{2}{ }^{0} \\
\mathrm{UO}_{2} \mathrm{Fu}^{0} \\
\mathrm{UO}_{2} \mathrm{Fu}_{2}{ }^{2-} \\
\mathrm{UO}_{2} \mathrm{Hu}^{+} \\
\mathrm{UO}_{2} \mathrm{Hu}_{2}{ }^{0} \\
\mathrm{UO}_{2}{ }^{+} \\
\mathrm{UO}_{2}{ }^{0} \\
\mathrm{U}(\mathrm{OH})_{3}{ }^{+}\end{array}$ \\
\hline
\end{tabular}

\section{Результаты}

\section{Состав пород карьера бутового камня}

Гнейсограниты куполов представлены среднезернистыми кварц-биотит-полевошпатовыми гнейсами кислого состава.

Li-сидерофиллитовые граниты представлены равномернозернистыми породами светло-серого и розового цветов, сложенные альбитом, кварцем, калишпатом, Li-сидерофиллитом, иногда циннвальдитом. Акцессорные минералы: флюорит, топаз, монацит, пирит, паризит, циркон, гематит, колумбит. Составы гранитов даны в работе [7].

Карьером вскрывается контакт апикальной части гранитов и гнейсогранитов. Контакт представлен 30ной штокшайдеров - краевых пегматитов, чередующихся с зонами аплитов, мощность зоны до 5 м, зона прослеживается в южной и восточной стенках. В гнейсогранитах над зоной штокшайдеров наблюдаются небольшие пегматитовые тела (до первых метров в поперечнике) кварц-калишпат-Liсидерофиллитового состава, без явного контакта с нижележащими гранитами, но вероятно связанные с внедрением последних. В зоне штокшайдеров также присутствуют участки, выполненные автомагматическими брекчиями. Граниты на нижних уступах карьера часто имеют пятна осветления, альбитизированы, трещины в них от первых миллиметров до сантиметра часто выполнены флюоритом, встречаются зоны соссюритизации. Вероятно, апикальная часть высокодифференцированных гранитов при их кристаллизации была богата летучими компонентами, в связи с чем широко проявлены изменения в результате автометасоматических процессов. В светлых альбитизированных разностях валовое содержание $U$ в породе падает до 1,7 ppm, в то время как в неальбитизированных разностях оно составляет 10,7. Валовые со- держания U в кислых породах Салминского батолита - от 3 до 10 ppm [8].

Главный минерал-концентратор U и Th в породах района исследований - это циркон, но также здесь были обнаружены и другие U- и Th-содержащие минералы: флюорит, монацит и карбонаты РЗЭ. Содержания U во флюорите, паризите и монаците по данным LA-ICP-MS составили: 0,4, 294 и 281 ppm, соответственно.

\section{Химический состав изучаемых вод и донных отложений}

Bce изученные воды являются пресными, нейтральными или слабощелочными, преимущественно гидрокарбонатными натриево-кальциевыми. В отдельных точках отмечены превышения предельно допустимой концентрации (ПДК) $\mathrm{Fe}, \mathrm{Mn}, \mathrm{Cu}, \mathrm{Zn}$, Mo, V (табл. 3). Сравнение проводилось с нормативом для водных объектов рыбохозяйственного значения [26]. В воде, отобранной из пегматитового карьера и используемой в качестве точки сравнения, отмечается превышение только по $\mathrm{Cu}$. Наибольшее превышение по вышеперечисленным химическим элементам наблюдается в водах, отобранных в непосредственной близости от разрабатываемого карьера бутового камня.

Графики, представленные на рис. 3, указывают на то, что при удалении от карьера бутового камня снижается величина минерализации и содержание макрокомпонентов, Sr, U, V, Mo, Zn, Cd. Содержание железа, наоборот, становится выше, что связано, по нашему мнению, с увеличением содержания органического вещества в воде.

Высокие по сравнению с другими пробами содержания Y, Ce и La отмечены в воде, сбрасываемой непосредственно из карьера (точка 1), и в р. Хепооя (точка 5). В донных отложениях максимальная концентрация Y, La, Ce также наблюдается в точке 1 (рис. 4). 
Таблица 3. Химический состав природных вод района разрабатываемого карьера бутового камня (2019 г.)

Table 3. Chemical composition of the natural waters of the rubble stone quarry area (2019)

\begin{tabular}{|c|c|c|c|c|c|c|c|c|}
\hline \multirow{2}{*}{$\begin{array}{l}\text { Компоненты и показатели } \\
\text { Components and parameters }\end{array}$} & \multirow{2}{*}{$\begin{array}{c}\text { Единица измерения } \\
\text { Unit }\end{array}$} & \multicolumn{7}{|c|}{ Номер точки пробоотбора/Sampling point number } \\
\hline & & 1 & 2 & 3 & 4 & 5 & 6 & 7 \\
\hline $\mathrm{pH}$ & ед. $\mathrm{pH} / \mathrm{pH}$ unit & 8,46 & 7,12 & 7,22 & 7,44 & 8,56 & 6,43 & 7,73 \\
\hline $\mathrm{M} / \mathrm{TDS}$ & $\mathrm{M \Gamma} / \Omega / \mathrm{mg} / \mathrm{L}$ & 210 & 217 & 199 & 196 & 94 & 49 & 101 \\
\hline ПОК/PI & $\mathrm{M \Gamma O} /$ л/mgO/L & 0,21 & 2,96 & 6,98 & 8,37 & 29,01 & 10,77 & 3,88 \\
\hline $\mathrm{HCO}_{3}^{-}$ & \multirow{8}{*}{$\begin{array}{c}\text { мг/л } \\
\mathrm{mg} / \mathrm{L}\end{array}$} & 110,04 & 120,78 & 112,24 & 111,02 & 53,07 & 20,13 & 53,25 \\
\hline $\mathrm{Cl}^{-}$ & & 19,88 & 15,27 & 18,46 & 17,75 & 9,98 & 9,98 & 8,45 \\
\hline $\mathrm{SO}_{4}{ }^{2-}$ & & 24,42 & 23,39 & 16,7 & 16,19 & 5,14 & 4,23 & 13,62 \\
\hline $\mathrm{Ca}^{2+}$ & & 27,25 & 30,86 & 25,05 & 24,65 & 15,43 & 5,77 & 17,7 \\
\hline $\mathrm{Mg}^{2+}$ & & 7,05 & 5,59 & 7,29 & 6,8 & 1,17 & 0,46 & 3,73 \\
\hline $\mathrm{Na}^{+}$ & & 17,9 & 17,5 & 16,2 & 16,1 & 7,52 & 1,16 & 1,84 \\
\hline $\mathrm{K}^{+}$ & & 2,42 & 2,61 & 2,16 & 2 & 0,97 & 0,36 & 0,92 \\
\hline $\mathrm{Fe}$ & & 0,02 & $<0,01$ & 0,06 & 0,08 & 0,6 & 0,39 & 0,06 \\
\hline $\mathrm{Mn}$ & \multirow{15}{*}{$\begin{array}{c}\text { мкг/л } \\
\mu \mathrm{g} / \mathrm{L}\end{array}$} & 25,88 & 10,69 & 0,88 & 1,89 & 7,85 & 19,55 & 1,3 \\
\hline $\mathrm{Al}$ & & 40 & 10 & 40 & 40 & 270 & 120 & 40 \\
\hline $\mathrm{Cu}$ & & 2,34 & 0,38 & $<0,1$ & 1,56 & 0,49 & 0,27 & 1,63 \\
\hline $\mathrm{Zn}$ & & 12,45 & 6,78 & 0,48 & 3,5 & 1,46 & 0,33 & 1,58 \\
\hline $\mathrm{Co}$ & & 0,14 & 0,05 & 0,09 & 0,12 & 0,14 & 0,1 & 0,04 \\
\hline $\mathrm{Ni}$ & & 0,53 & 0,2 & 0,22 & 0,51 & 0,4 & 0,06 & 1,67 \\
\hline $\mathrm{Cd}$ & & 0,17 & 0,14 & 0,11 & 0,14 & 0,07 & $<0,01$ & 0,02 \\
\hline Cs & & 0,07 & 0,13 & 0,1 & 0,1 & 0,07 & 0,02 & 0,03 \\
\hline $\mathrm{Sr}$ & & 0,12 & 0,13 & 0,12 & 0,12 & 0,06 & 0,01 & 0,03 \\
\hline Mo & & 32,41 & 36,88 & 33,17 & 29,84 & 12,22 & 0,07 & 0,21 \\
\hline $\mathrm{V}$ & & 1,32 & 1,03 & 0,95 & 0,93 & 0,67 & 0,35 & 0,16 \\
\hline $\mathrm{U}$ & & 90,37 & 49,74 & 14,21 & 12,34 & 3,28 & 0,08 & 4,94 \\
\hline $\mathrm{Y}$ & & 0,0118 & 0,0007 & 0,0002 & 0,0002 & 0,0014 & 0,0004 & 0,0002 \\
\hline $\mathrm{La}$ & & 0,00058 & 0,00003 & 0,00006 & 0,00008 & 0,00066 & 0,00037 & 0,00017 \\
\hline $\mathrm{Ce}$ & & 0,00044 & 0,00008 & 0,00011 & 0,00013 & 0,00127 & 0,00068 & 0,00024 \\
\hline
\end{tabular}

Примечания: $М$-минерализачия; ПОК - перманганатная окисляемость; жирным выделены содержания, превышающие ПДК для водных объектов рыбохозяйственного значения.

Notes: TDS - total dissolved solids; PI - permanganate index; bold type indicates contents exceeding the maximum permissible level for water bodies of fishery significance.
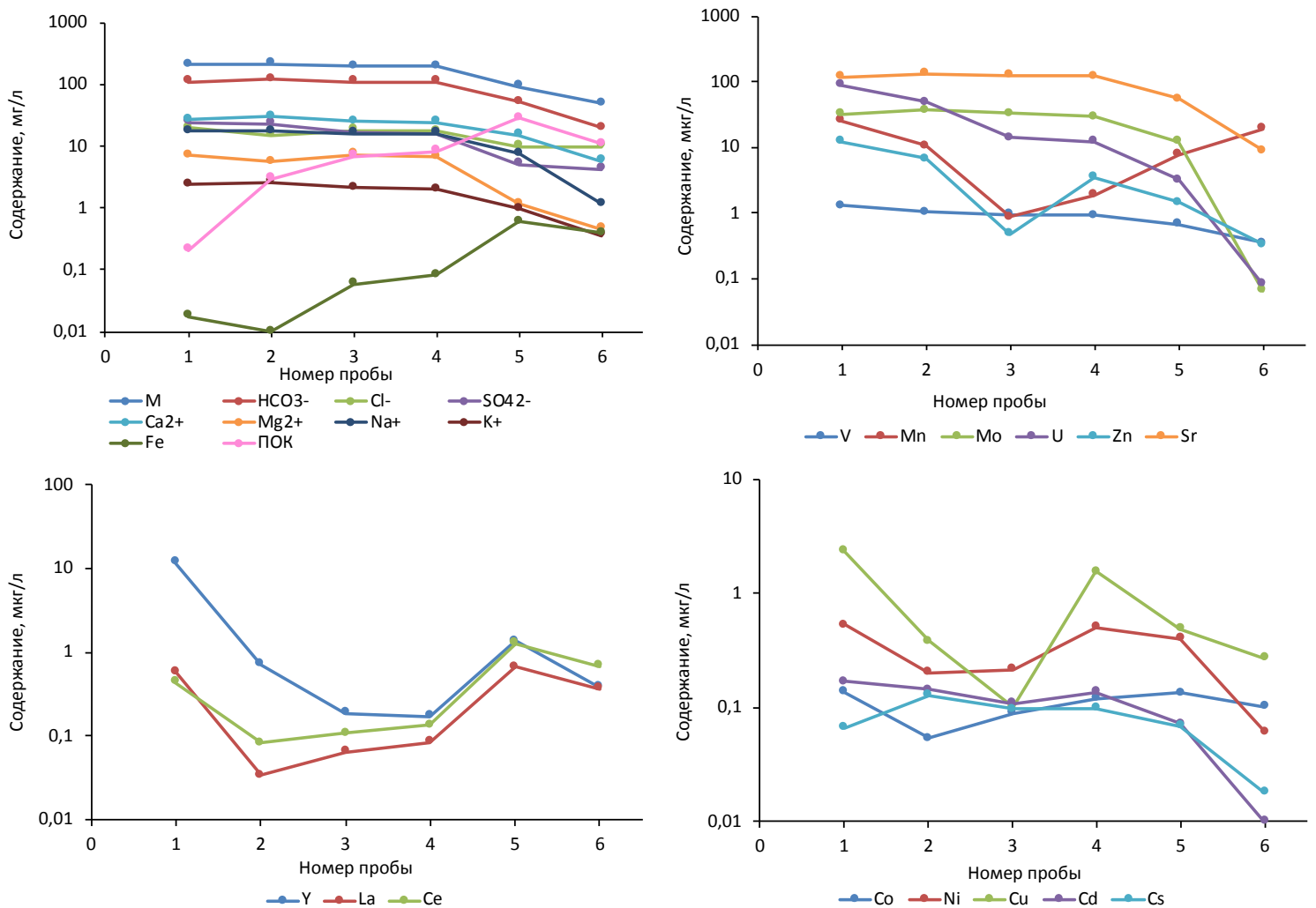

Pис. 3. Изменения химического состава воды в зависимости от удаленности от карьера. Условные обозначения: М-минерализачия; ПОК - перманганатная окисляемость

Fig. 3. Changes in the chemical composition of the studied water depending on the distance from the quarry. Legend: $M-$ total dissolved solids; ПОК - permanganate index 
В донных отложениях подобный пик содержания в точке 1 также характерен для $\mathrm{Fe}, \mathrm{Mn}, \mathrm{Co}, \mathrm{Cu}, \mathrm{Zn}$ и $\mathrm{Cs}$ (рис. 4). В то же время максимальное содержание U (831,36 мкг/г) наблюдается в истоке ручья (точка 2), вытекающего из водоема, куда происходит сброс воды из карьера бутового камня (рис. 4), далее по потоку его концентрация снижается, оставаясь достаточно высокой $(178,86$ мкг/г) лишь в точке 3 (тот же ручей, вниз по течению). Похожим поведением характеризуется $\mathrm{Ca}$, пик содержания для которого также отмечается в точке 2 и далее снижается вниз по потоку вплоть до точки 6 (р. Уксуньйоки), где наблюдается некоторое повышение его концентрации в донных отложениях.

Что касается содержания органического вещества, то его массовая доля достигает максимальных
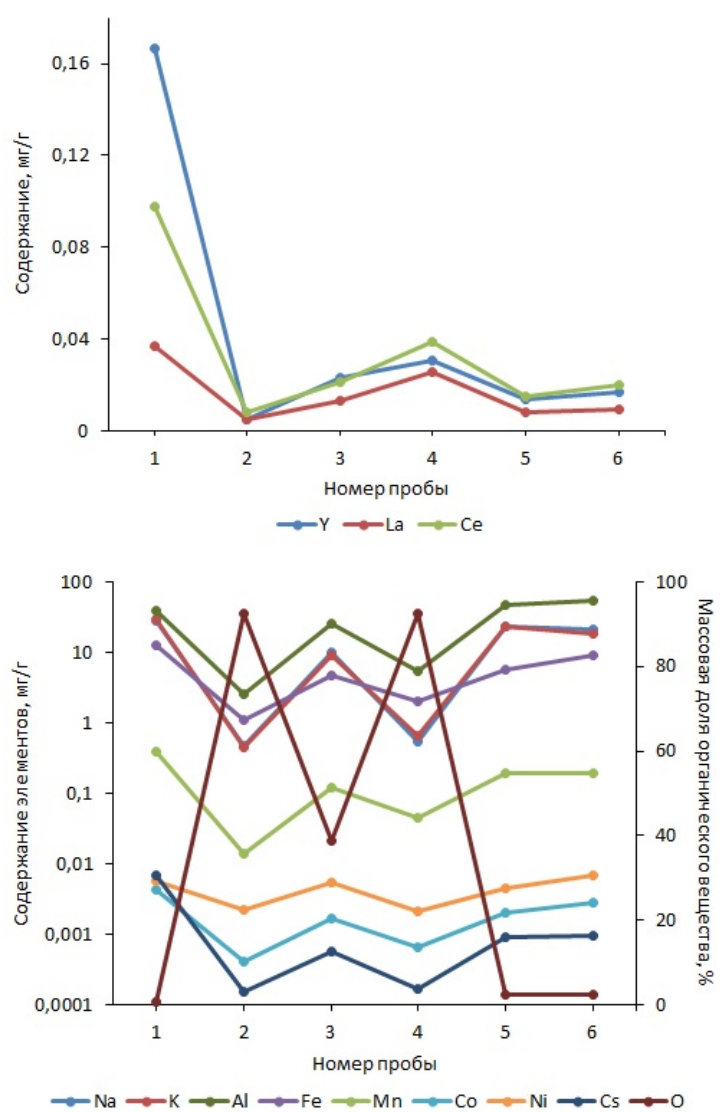

значений (до 92,6 \%) в пробе, отобранной в истоке ручья (точка 2), и ниже по течению в пределах заболоченной местности (точка 4). В водоеме - приемнике сброса из карьера бутового камня (точка 1), а также в донных отложениях р. Хепооя и Уксуньйоки (точки 5,6 ) его содержание минимально (рис. 4). Полученные данные хорошо согласуются с полевыми наблюдениями, описанными в соответствующем разделе. Со значением массовой доли органического вещества обратно коррелируют содержания ряда химических элементов: концентрации $\mathrm{Na}, \mathrm{K}, \mathrm{Al}, \mathrm{Fe}, \mathrm{Mn}, \mathrm{Co}, \mathrm{Ni}, \mathrm{Cs}$ (рис. 4) уменьшаются в пробах с высоким содержанием органики и достигают максимальных значений в пробах с низким ее содержанием.
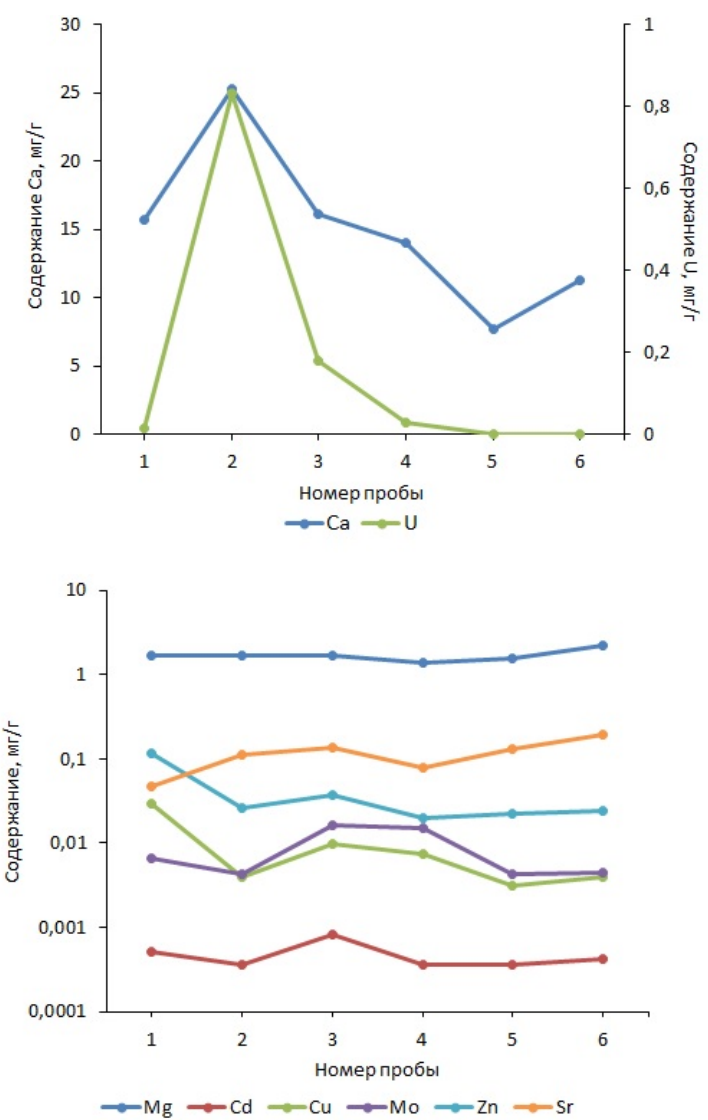

Рис. 4. Изменения химического состава донных отложений в зависимости от удаленности от карьера. Условные обозначения: $O$ - массовая доля органического вещества

Fig. 4. Changes in the chemical composition of the bottom sediments depending on the distance from the quarry. Legend: $O$ - weight percent of organic matter

\section{Результаты термодинамических расчетов}

Термодинамические расчеты насыщения изучаемых вод относительно заданных минералов показали следующие результаты. Гиббсит выпадает во всех пробах (табл. 4). Доломит и гетит осаждаются из воды, отобранной из водоема - приемника сбросов (точка 1), и в речных водах (точки 5 и 6). Вода пегматитового карьеpa (точка 7) насыщена относительно сидерита, но выпадает он в весьма незначительном количестве.

Вода, отобранная из водоема - приемника сбросов (точка 1), и связанного с ним ручья (точки 2, 3, 4), а также вода пегматитового карьера (точка 7) насыще- на относительно уранинита, он выпадает в количестве от 0,0055 (проба 7) до 0,1 (проба 1) мг из 1 литра раствора. При этом в общем балансе урана эти массы осаждающихся минералов составляют 99,99 \%. Выпадение урана из раствора косвенно подтверждается результатами химического анализа донных органоминеральных отложений. Максимальное содержание $\mathrm{U}(831,36$ мкг/г) наблюдается в донных отложениях в истоке ручья, сформированного сбрасываемыми из карьера водами (точка 2), далее по потоку его концентрация снижается, оставаясь достаточно высокой (178,86 мкг/г) лишь в точке 3 (донные отложения того 
же ручья, вниз по течению). В донных отложениях пик содержания марганца, кобальта, цинка, меди и цезия, как уже отмечалось выше, наблюдается в 1 точке. Однако мы не зафиксировали осаждения ми- нералов, содержащих вышеперечисленные элементы. Возможным механизмом накопления металлов в донных отложениях в данном случае является сорбция на глинистых частицах.

Таблица 4. Массы минералов, выпадающих из водных растворов (мг/л)

Table 4. Mass of minerals precipitated from the aqueous solutions $(\mathrm{mg} / \mathrm{L})$

\begin{tabular}{|c|c|c|c|c|c|c|c|}
\hline \multirow{2}{*}{$\begin{array}{c}\text { Минерал } \\
\text { Мineral }\end{array}$} & \multicolumn{7}{|c|}{ Номер точки пробоотбора/Sampling роint number } \\
\cline { 2 - 8 } & 1 & 2 & 3 & 4 & 5 & 6 & 7 \\
\hline $\begin{array}{c}\text { Гиббсит } \\
\text { Gibbsite }\end{array}$ & 0,12 & 0,029 & 0,12 & 0,12 & 0,78 & 0,78 & 0,12 \\
\hline $\begin{array}{c}\text { Кальцит } \\
\text { Саlсіte }\end{array}$ & 0 & 0 & 0 & 0 & $1,10 \mathrm{E}-06$ & $1,10 \mathrm{E}-06$ & 0 \\
\hline $\begin{array}{c}\text { Доломит } \\
\text { Dolomite }\end{array}$ & 8,7 & 0 & 0 & 0 & 0,72 & 0,72 & 0 \\
\hline $\begin{array}{c}\text { Сидерит } \\
\text { Siderite }\end{array}$ & 0 & 0 & 0 & 0 & 0 & 0 & $1,10 \mathrm{E}-06$ \\
\hline $\begin{array}{c}\text { Гётит } \\
\text { Gоеthite }\end{array}$ & 0,016 & 0 & 0 & 0 & $3,60 \mathrm{E}-06$ & $3,60 \mathrm{E}-06$ & 0 \\
\hline $\begin{array}{c}\text { Уранинит } \\
\text { Чraninite }\end{array}$ & 0,1 & 0,056 & 0,016 & 0,014 & 0 & 0 & 0,0055 \\
\hline
\end{tabular}

Основные катионы находятся в изученных водах преимущественно в ионной форме. Доля $\mathrm{Ca}^{2+}$ составляет 96,64-99,55 мол. \%, $\mathrm{Mg}^{2+}-96,43-99,41$ мол. \%, $\mathrm{Na}^{+}-99,69-99,99$ мол. \%, $\mathrm{K}^{+}-99,59-99,97$ мол. \%. Другими формами нахождения для кальция являются $\mathrm{CaHCO}_{3}{ }^{-}$(до 1,53 мол. \%), $\mathrm{CaCO}_{3}{ }^{0}$ (до 1,31 мол. \%), $\mathrm{CaSO}_{4}{ }^{0}$ (до 1,70 мол. \%). В формах нахождения магния кроме основной ионной можно отметить $\mathrm{MgHCO}_{3}{ }^{-}$(до 1,48 мол. \%) и $\mathrm{MgSO}_{4}{ }^{0}$ (до 2,22 мол. \%). Фульватные комплексы кальция и магния имеют подчиненное значение: $\mathrm{MgFu}^{0}$ до 0,03 и $\mathrm{CaFu}^{0}$ до 0,02 мол. \%. Стронций, подобно основным катионам, находится преимущественно в ионной форме (97,31-99,84 мол. \%). Значение гидрокарбонатного комплекса стронция невелико (до 2,17 мол. \%). Доля сульфаных, фульватных и гуматных комплексов незначительна. Кроме основных катионов и стронция преимущественно в ионной форме находятся марганец, цинк, кадмий, никель, медь и кобальт (рис. 5). Другими формами нахождения вышеперечисленных металлов являют гидрокарбонатные и сульфатные. В воде истока ручья (точка 2) отмечена высокая, по сравнению с другими пробами, доля фульватного комплекса $\mathrm{CuFu}^{0}(1,17$ мол. \%).

Железо образует устойчивый комплекс $\mathrm{Fe}(\mathrm{OH})_{2} \mathrm{Fu}$ (рис. 5), что препятствует выпадению гидроксида железа и способствует накоплению железа в водном растворе в высоких концентрациях. В точке 1 вода характеризуется низким содержанием органического вещества. Количество выпавшего здесь гетита по результатам расчета наибольшее $(0,016$ мг/л) по сравнению с другими точками опробования. По данным анализа донных отложений в этой точке также наблюдается пик содержания железа (12,5 мг/г). Ранее при исследовании другого объекта в Питкярантском рудном районе [27] термодинамическим расчетом форм нахождения металлов показано образование комплекса $\mathrm{Fe}(\mathrm{OH})_{2} \mathrm{Fu}^{-}$. Образование фульватных комплексов железа продемонстрировано термодинамическими расчетами на примере других регионов России [28]. Приведенные в [29] ряды активности ме- таллов демонстрируют высокое сродство железа и гумусового вещества в озерах Европейской территории России и Западной Сибири.

Алюминий находится в растворе преимущественно в комплексе $\mathrm{Al}(\mathrm{OH})_{3}{ }^{0}$. В воде р. Уксуньйоки (точка 6), характеризующейся наименьшей величиной $\mathrm{pH}$, высока доля комплекса $\mathrm{Al}(\mathrm{OH})_{2}{ }^{+}$(более 40 мол. \%). Полученные результаты достаточно хорошо согласуются с выводами, полученными [30, 31]. Отсутствие комплексов алюминия с гумусовыми веществами объясняется присутствием в воде железа в значительных концентрациях, которое имеет сильное сродство с органическим веществом и связывает практически все количество заданной в баланс фульвокислоты. Влияние железа на процессы комплексообразования алюминия с гумусовыми веществами также затронуто в работе [31]. Очевидно, что в нашем случае конкуренцию алюминию за связывание с растворенным органическим веществом составляют редкоземельные элементы (РЗЭ), поведение которых будет рассмотрено ниже.

Основными формами нахождения урана в природных водах исследуемого района являются $\mathrm{UO}_{2}{ }^{0}$ и карбонатные комплексы уранила (рис. 5). При более восстановительных условиях (Eh ниже $-60 \mathrm{MB}$ ) практически весь уран находится в форме $\mathrm{UO}_{2}{ }^{0}$ (точки 1,6 , 7). При повышении величины Eh доминирует U(VI) (точки 2, 3, 5). В воде ручья, отобранной в пределах заболоченной территории (точка 4), доля $\mathrm{UO}_{2}{ }^{0}$ велика, однако доля карбонатных комплексов также значительна (более 40 мол. \%). Заметно отличается распределение форм урана в воде р. Уксуньйоки (точка 6). Здесь практически отсутствуют карбонатные комплексы уранила из-за низкого содержания гидрокарбонат-иона (20,13 мг/л). Содержание гидроксо-форм уранила во всех точках незначительно: $\mathrm{UO}_{2} \mathrm{OH}^{+}$(до 0,03 мол. $\%$ ) и $\mathrm{UO}_{2}(\mathrm{OH})_{2}{ }^{0}$ (до 0,21 мол. \%). $\mathrm{U}(\mathrm{V})$ существует в воде в форме $\mathrm{UO}_{2}{ }^{+}$до 0,02 мол. \%. Роль фульватных и гуматных комплексов уранила ничтожно мала (до $2 * 10^{-7}$ мол. \%). 

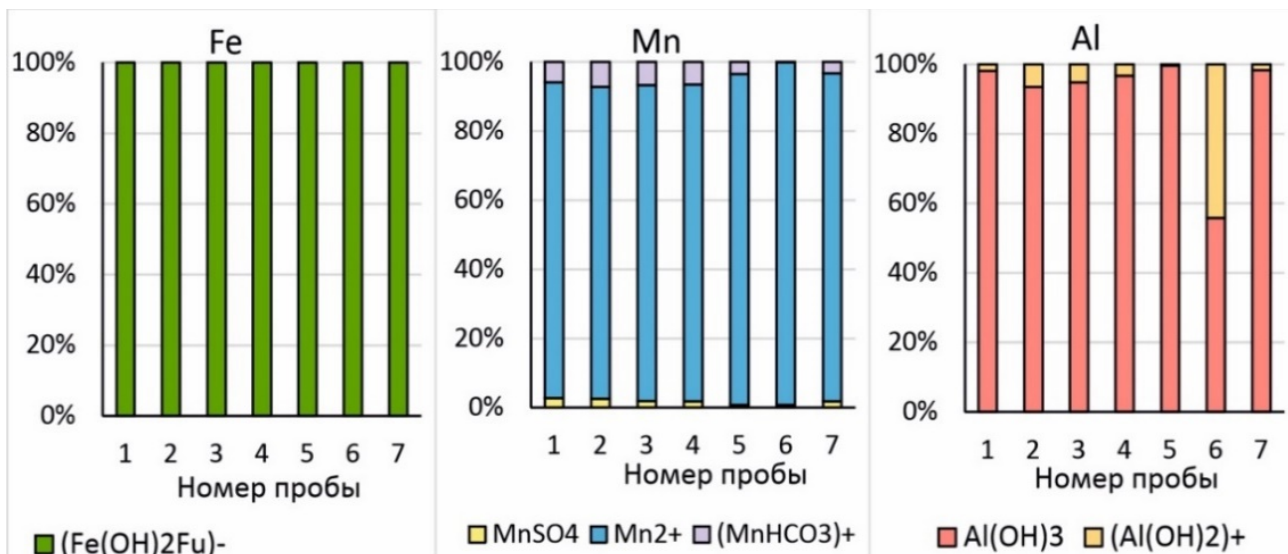

$\square(\mathrm{Fe}(\mathrm{OH}) 2 \mathrm{Fu})-$

$\square \mathrm{MnSO} 4 \mathrm{Mn} 2+\square(\mathrm{MnHCO})+$
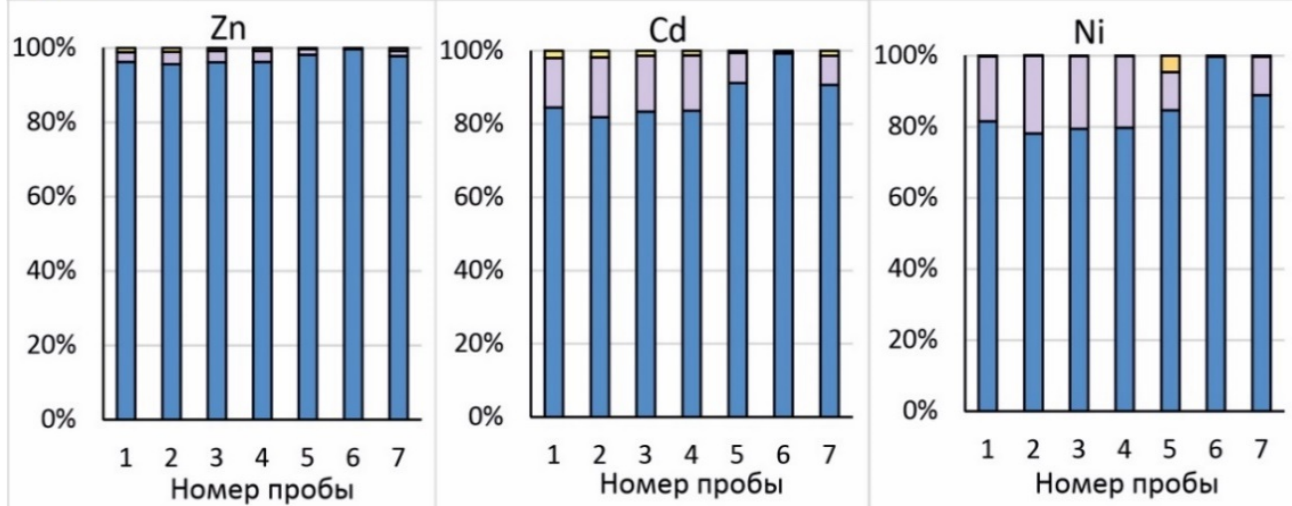

$\square \mathrm{Zn} 2+\square(\mathrm{ZnHCO})+\square \mathrm{ZnSO} 4$

$\square \mathrm{Cd} 2+\square(\mathrm{CdHCO})+\square \mathrm{CdSO} 4$
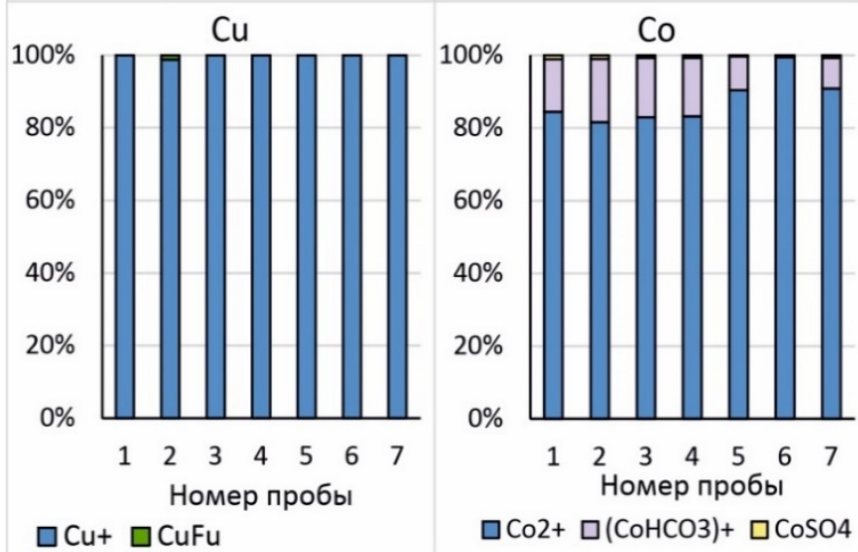

$\square \mathrm{Ni} 2+\square(\mathrm{NiHCO})+\square \mathrm{Ni}(\mathrm{OH}) 2$

$\square \mathrm{Cu}+\square \mathrm{CuFu}$

$\square \mathrm{Co} 2+\square(\mathrm{CoHCO} 3)+\square \mathrm{CoSO} 4$
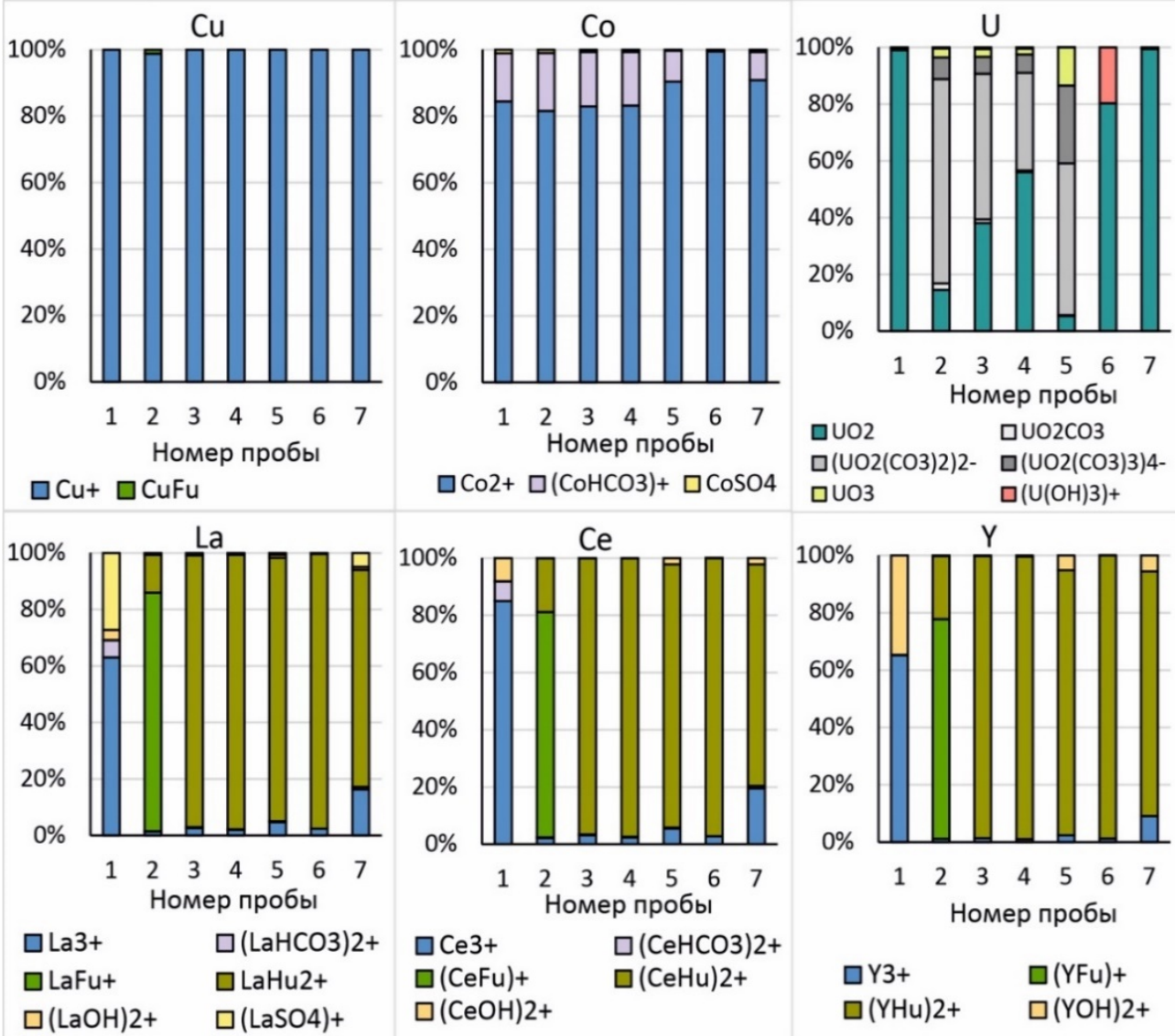

Рис. 5. Основные формы нахождения металлов в природных водах исследуемого района

Fig. 5. Metal speciation in natural water of the study area 
Что касается миграции РЗЭ, то в воде точки 1 при низком содержании органического вещества рассмотренные нами лантан, церий и иттрий находятся в ионной и гидроксоформах (рис. 5). Для лантана существенную роль в этой точке также играет комплекс с сульфат-ионом, небольшое количество которого также фиксируется в точке 7. Сродство La с сульфатионом ранее было показано в работе [32] для ряда рек Дальнего Востока России, однако причина преобладания сульфатных комплексов над карбонатными, которые считаются более распространенными при комплексообразовании РЗЭ в нейтральных и щелочных водах, в работе не обсуждается. Вероятно, здесь играет роль низкое значение отношения $\mathrm{HCO}_{3}{ }^{-} / \mathrm{SO}_{4}{ }^{2-}$ в воде и повышенная концентрация урана, который имеет высокую степень сродства с карбонат- и гидрокарбонат-ионами. Термодинамические расчеты показали также высокую степень сродства лантана, церия и иттрия с органическим веществом, что соответствует выводам, сделанным в работах [33, 34]. Как и в случае с неорганическими лигандами, при образовании органоминеральных комплексов также следует учитывать конкурентное комплексообразование [34] Так, в воде, отобранной в истоке ручья (точка 2), при низком содержании железа и высоком содержании фульвокислоты железо не связывает всю фульвокислоту и она образует комплексы с лантаном, церием, иттрием, а также с медью. Однако с удалением от карьера в воде повышается концентрация железа, и оно связывает практически всю фульвокислоту в комплекс $\mathrm{Fe}(\mathrm{OH})_{2} \mathrm{Fu}^{-}$. При этом гуминовая кислота с железом не связывается, и в точках 3-6 преобладающими формами для лантана, церия и иттрия становится именно гуматные комплексы.

\section{Заключение}

Среди геохимических процессов формирования химического состава природных вод района исследо-

\section{СПИСОК ЛИТЕРАТУРЫ}

1. Dutova E.M. Geochemistry of fresh groundwater in the AltaiSayan folded area and adjacent areas of the West Siberian plate // Applied Geochemistry. - 2020. - V. 120. - 104673.

2. Rare earth elements in a historical mining district (south-wes Spain): Hydrogeochemical behaviour and seasonal variability Raúl Moreno / R.M. Gonzalez, C.R. Canovas, M. Olías, F. Macías // Chemosphere. -2020 . - V. 253. - 126742

3. Origin and geochemistry of arsenic in surface and groundwaters of Los Pozuelos basin, Puna region, Central Andes, Argentina / J. Murray, D.K. Nordstrom, B. Dold, M.R. Orué, A. Kirschbaum // Science of the Total Environment. - 2019. - V. 697. - 134085.

4. Ларин А.М. Граниты рапакиви и ассоциирующие породы. СПб.: Наука, 2011. - 402 с.

5. Борисов И. История горного дела Северного Приладожья (XVII в. - 1939 г.). - Сортавала: Сортавальский полиграф, 2009. $-41 \mathrm{c}$.

6. Объемная модель Салминского массива гранитов рапакиви и закономерности размещения оруденения / А.А. Духовский, Н.А. Артамонова, Э.И. Иванова, И.О. Никифоров // Отечественная геология - 1994. - № 4. - С. 24-32.

7. Конышев А.А., Чевычелов В.Ю., Шаповалов В.Ю. Два типа высокодифференцированных топазсодержащих гранитов Салминского батолита, южная Карелия // Геохимия. - 2020. № 1. - C. 14-30 ваний наиболее важными являются процессы комплексообразования и осаждения минералов, а также окислительно-восстановительные реакции. Поведение урана в изучаемых водах в первую очередь зависит от окислительно-восстановительных условий. Также важным фактором миграции урана является присутствие в воде карбонат-иона, с которым уранил образует устойчивые комплексы. Роль органического вещества в изученных водах высока для процесса накопления железа в воде за счет образования устойчивого гидроксо-фульватного комплекса железа. В пробах с низким содержанием органического вещества железо выпадает в виде гетита. Важна роль органического вещества и при миграции РЗЭ, которые склонны связываться с гуминовой кислотой. Также на примере РЗЭ (образование комплекса $\mathrm{LaSO}_{4}^{+}$, pacпределение органоминеральных комплексов Р3Э) очевидна важность учета конкурентного комплексообразования при изучении форм нахождения элементов, когда соотношение одних компонентов водного раствора существенно влияет на перераспределение форм миграции других. Можно предположить, что немаловажную роль в выводе металлов из водного раствора играет процесс сорбции на глинистых частицах. В будущем планируется изучить роль сорбции в формировании состава вод данного района.

Проведенная работа позволяет сделать заключение о том, что эксплуатация карьера бутового камня вносит вклад в перераспределение химических элементов в изучаемом районе. Учитывая длительность эксплуатации карьера и высокие концентрации ряда элементов в донных отложениях водных объектов, сформированных в результате сброса воды из карьера, это влияние может быть достаточно существенным.

Авторы благодарят Марию Олеговну Аносову и Андрея Юрьевича Бычкова за помощь в осуществлении аналитических работ.

8. Larin A., Beljaev A., Stepanov K. Geological setting of the Salmi batholith // Salmi batholith and Pitkaranta ore field in Soviet Karelia / Eds. I. Haapala, O.T. Ramo, P.T. Salonsaari. Guide 33. Finland: University of Helsinki, 1991. - P. 6-7.

9. Amelin Yu.V., Larin A.M., Tucker R.D. Chronology of multiphase emplacement of the Salmi rapakivi graniteanorthosite complex, Baltic Shield: implications for magmatic evolution // Contribution to Mineralogy and Petrology. - 1997. - V. 127. № 4. - P. 353-368.

10. Методы геохимического моделирования и прогнозирования в гидрогеологии / С.Р. Крайнов, Ю.В. Шваров, Д.В. Гричук, Е.В. Добровольский, Г.А. Соломин, М.В. Борисов, Б.Н. Рыженко, Л.И. Матвеева, В.И. Лялько, В.М. Швец. - М.: Недра, 1988. $-254 \mathrm{c}$.

11. Букаты М.Б. Рекламно-техническое описание программного комплекса HydroGeo. Номер гос. регистрации алгоритмов и программ во Всероссийском научно-техническом информационном центре (ВНТИЦ) № 50200500605. - М.: ВНТИЦ, 2005. $-7 \mathrm{c}$.

12. Изучение органических веществ поверхностных вод и их взаимодействие с ионами металлов / Г.М. Варшал, И.Я. Кошеева, И.С. Сироткина, Т.К. Велюханова, Л.Н. Инцкирвели, Н.С. Замокина // Геохимия. - 1979. - № 4. - С. 598-607.

13. Липатникова О.А., Гричук Д.В. Термодинамическое моделирование форм нахождения тяжелых металлов в донных отложения на примере Иваньковского водохранилища // Вестник 
Московского Университета Сер. 4. Геология. - 2011. - № 2. C. $5-59$.

14. Mantoura R.F.C., Dickson A., Riley S.P. The complexation of metals with humic materials in natural waters // Estuarine and Coastal Marine Science. - 1978. - V. 6. - P. 387-408.

15. Процессы миграции и формы нахождения химических элементов в поровых водах донных отложений в Иваньковском водохранилище / В.В. Красинцева, Д.В. Гричук, Г.И. Романова, А.И. Кадукин // Геохимия. - 1982. - № 9. - С. 1342-1354.

16. Об ассоциации фульвокислот в водных растворах / Г.М. Варшал, И.С. Инцкирвели, И.С. Сироткина, И.В. Колосов, И.Я. Кощеева // Геохимия. - 1975. - № 10. - С. 1581-1585.

17. Impact of competitive $\mathrm{Fe}$ (III) ion on the complexation of humic acid and toxic metal ions / Y. Yamamoto, F. Kita, N. Isono, S. Imai // The Japan Society for Analitical Chemistry. - 2017. V. 66. - № 12. - P. 875-883.

18. Elkins K.M., Nelson J. Fluorescence and FT-IR spectroscopic studies of Suwannee river fulvic acid complexation with aluminium, terbium and calcium // Journal of Inorganic Biochemistry. - 2001. - V. 87. - P. 81-96.

19. Изучение химических форм элементов в поверхностных водах / Г.М. Варшал, Т.К. Велюханова, И.Я. Кощеева, В.А. Дорофеева, Н.С. Баучидзе, О.Г. Касимова, Г.А. Махарадзе // Журнал аналитической химии. - 1983. - № 38. - С. 1590-1600.

20. Guy R.D., Charabarti C.L. Studies of metal- organic interactions in model systems pertaining to naturals water // Canadian Journal of Chemistry. - 1976. - V. 54. - № 16. - P. 2600-2611.

21. Stevenson F.J. Stability constants of $\mathrm{Cu} 2+, \mathrm{Pb} 2+$ and $\mathrm{Cd} 2+$ complexes with humic acids // Soil Science Society of America Journal. - 1976. - V. 40. - № 5. - P. 665-672.

22. Комплексообразование благородных металлов с фульвокислотами природных вод и геохимическая роль этих процессов / Г.М. Варшал, Т.К. Велюханова, И.Я. Кощеева, И.В. Кубракова, Н.Н. Баранова // Аналитическая химия редких элементов. - М. Наука, 1988. - С. 112-146.

23. Complexation thermodynamics of Sr (II) and humic acid / M Samadfam, Y. Niitsu, S. Sato, H. Ohashi // Radiochimica Acta. 1996. - V. 73. - P. 211-216.

24. Uranium(VI) complexation with citric, humic and fulvic acids / J.J. Lenhart, S.E. Cabaniss, P. MacCarthy, B.D. Honeyman // Radiochimica Acta. - 2000. - V. 88. - P. 345-353.

25. Sonke J.E., Salters V.J.M. Lanthanide-humic substances complexation. I Experimental evidence for a lanthanide contraction effect // Geochimica et Cosmochimica Acta. - 2006. V. 70. - P. 1495-1506.

26. Приказ от 13 декабря 2016 года N 552 «Об утверждении нормативов качества воды водных объектов рыбохозяйственного значения, в том числе нормативов предельно допустимых концентраций вредных веществ в водах водных объектов рыбохозяйственного значения» (с изменениями от 12 октября 2018 года).

27. Формы миграции тяжелых металлов и химический состав поверхностных вод в районе шахты «Мышьяковая» (Питкярантский рудный район, южная Карелия) / А.А. Конышев, Е.С. Сидкина, Е.В. Черкасова, М.В. Мироненко, А.Г. Гридасов, А.В. Жилкина, И.А. Бугаев // Геохимия. - 2020. - № 9. C. $930-936$.

28. Озеро Эбейты, Россия: химико-органический и минеральный состав воды и донных отложений / М.Н. Колпакова, О.Л. Гаськова, О.С. Наймушина, С.К. Кривоногов // Известия Томского политехнического университета. Инжиниринг георесурсов. - 2018. - Т. 329. - № 1. - С. 111-123.

29. Дину М.И. Геохимические особенности распределения элементов по формам существования в озерах Европейской территории России и Западной Сибири // Геохимия. - 2018. № 10. - С. 988-997.

30. Lee Y.H. Aluminium speciation in different water types // Ecological Bulletins. - 1985. - V. 37. - P. 109-119.

31. Courtign E., Vandecasteele C., Dams R. Speciation of aluminium in surface water // Science of the Total Environment. - 1990. V. 90. - P. 191-202.

32. Харитонова Н.А., Вах Е.А. Редкоземельные элементы в поверхностных водах Амурской области. Особенности накопления и фракционирования // Вестник Томского государственного университета. - 2015. - Т. 396. - С. 232-244.

33. Distribution, speciation, and bioavailability of lanthanides in the Rhine-Meuse Estuary, the Netherlands / C.T.A. Moermond, J. Tijink, A.P. van Wezel, A.A. Koelmans // Environmental Toxicology and Chemistry. - 2001. - V. 20. - № 9. - P. 1916-1926.

34. Tang J., Johannesson K.H. Speciation of rare earth elements in natural terrestrial waters: Assessing the role of dissolved organic matter from the modeling approach // Geochimica et Cosmochimica Acta. - 2003. - V. 67. - № 13. - P. 2321-2339.

Поступила 31.08.2020 2.

\section{Информация об авторах}

Конышев $\boldsymbol{A} . \boldsymbol{A}$., кандидат геолого-минералогических наук, научный сотрудник лаборатории моделирования гидрогеохимических и гидротермальных процессов Института геохимии и аналитической химии им. В.И. Вернадского РАН.

$\boldsymbol{C u д к и н а ~} \boldsymbol{E . C . , ~ к а н д и д а т ~ г е о л о г о - м и н е р а л о г и ч е с к и х ~ н а у к , ~ р у к о в о д и т е л ь ~ л а б о р а т о р и и ~ м о д е л и р о в а н и я ~ г и д р о г е о х и - ~}$ мических и гидротермальных процессов Института геохимии и аналитической химии им. В.И. Вернадского РАН.

Cолдатова $\boldsymbol{E} . \boldsymbol{A}$., кандидат геолого-минералогических наук, старший научный сотрудник лаборатории моделирования гидрогеохимических и гидротермальных процессов Института геохимии и аналитической химии им. В.И. Вернадского РАН.

Догадкин Д.Н., кандидат химических наук, научный сотрудник лаборатории методов исследования веществ и материалов Института геохимии и аналитической химии им. В.И. Вернадского РАН.

Громяк И.Н., научный сотрудник лаборатории методов исследования веществ и материалов Института геохимии и аналитической химии им. В.И. Вернадского РАН. 
UDC 550.461

\title{
FEATURES OF CHEMICAL ELEMENT BEHAVIOR IN THE WATER-ROCK SYSTEM OF THE RUBBLE STONE QUARRY IN PITKÄRANTA DISTRICT (KARELIA)
}

\author{
Artem A. Konyshev 1 , \\ icelopa@gmail.com
}

\section{Evgeniya S. Sidkina ${ }^{1}$,} sidkinaes@yandex.ru

\section{Evgeniya A. Soldatova ${ }^{1}$, 2a61@mail.ru}

\section{Denis N. Dogadkin ${ }^{1}$, denisnd@mail.ru}

Irina N. Gromyak', gnom.motl@bk.ru

\author{
1 Vernadsky Institute of Geochemistry and Analytical Chemistry RAS, \\ 19, Kosygin street, Moscow, 119991, Russia.
}

The relevance. The study of the chemical element distribution in the water-rock system in areas of active development of mineral deposits is relevant because of the potential impact of these processes on environmental conditions. It changes the geochemical conditions of the natural environment. It is particularly important for the area under study, which is a part of the catchment of the largest natural fresh water reservoir in Europe - Lake Ladoga.

The research aimed to study the aqueous removal of chemical elements from granitoid rocks opened-up by the quarry and the behavior of these elements in natural waters and bottom sediments of the region.

The study objects are the natural waters and bottom sediments of the rubble stone quarry area (Pitkäranta ore district, Karelia). The authors traced the changes in the chemical composition of natural waters and associated bottom sediments as the water moves from its discharge from the quarry to inflow into the river network.

Methods. The analysis of the chemical composition of natural waters and bottom sediments was carried out by standard methods: potentiometry, titrimetry, ICP-AES, ICP-MS. The study of the mineral composition of the quarry rocks was carried out using LA-ICP-MS. The chemical composition of the rocks was studied by XRF, ICP-MS, and ICP-AES. Thermodynamic modeling of metal speciation in natural waters and secondary mineral precipitation was conducted by the HydroGeo software package. The model was verified based on the analysis of the chemical composition of bottom sediments.

Results. In the studied water bodies, an excess of the maximum permissible concentration of $\mathrm{Fe}, \mathrm{Mn}, \mathrm{Cu}, \mathrm{Zn}, \mathrm{Mo}, \mathrm{V}$ at some points was found. The value of total dissolved solids and the content of the main components and Sr, U, V, Mo, Zn, Cd decrease with the increase of distance from the rubble stone quarry. The concentration of Fe increases due to the growth in the content of organic matter in the water. In bottom sediments, the maximum concentrations of many elements ( $\mathrm{Fe}, \mathrm{Mn}, \mathrm{Co}, \mathrm{Cu}, \mathrm{Zn}, \mathrm{Cs}, \mathrm{Ce}, \mathrm{La}, \mathrm{Y}$ ) is detected at the point of water discharge from the quarry. The maximum $U$ content is observed slightly downstream from the mentioned point. It is consistent with the data on the composition of bottom sediments and modeling data, which indicate the possibility of uraninite precipitation from an aqueous solution in the point of water discharge from the quarry and the stream source originating in the discharge point. The role of organic matter is essential for $\mathrm{Fe}$ accumulation in water due to the formation of a stable hydroxo-fulvate complex of Fe and rare earth elements due to the formation of complexes with humic acids. Analysis of the metal distribution and speciation and secondary mineral precipitation allowed us to conclude that the exploitation of the rubble stone quarry affects the redistribution of chemical elements in the study area significantly.

\section{Key words:}

Water-rock system, leaching, metal speciation, mineral precipitation, fulvic acids, humic acids, dissolved organic matter, thermodynamic calculation, uranium, complexation.

The authors appreciate Mariya O. Anosova and Andrey Yu. Bychkov for their help with chemical and mineralogical analysis.

\section{REFERENCES}

1. Dutova E.M. Geochemistry of fresh groundwater in the AltaiSayan folded area and adjacent areas of the West Siberian plate. Applied Geochemistry, 2020, vol. 120, 104673.

2. Gonzalez R.M, Canovas C.R., Olías M., Macías F. Rare earth elements in a historical mining district (south-west Spain): Hydrogeochemical behaviour and seasonal variability Raúl Moreno Chemosphere, 2020, vol. 253, 126742

3. Murray J., Nordstrom D.K., Dold B, Orué M. R., Kirschbaum A Origin and geochemistry of arsenic in surface and groundwaters of Los Pozuelos basin, Puna region, Central Andes, Argentina Science of the Total Environment, 2019, vol. 697, 134085.
4. Larin A.M. Granity rapakivi i asotsiiruyushchie porody [Rapakivi granites and associated rocks]. Saint-Petersburg, Nauka Publ., 2011. $402 \mathrm{p}$

5. Borisov I. Istoriya gornogo dela Severnogo Priladozhya (XVII v. 1939 g.) [The history of mining in the Northern Ladoga area (XVII - 1939)]. Sortavala, Sortavalskiy poligraf, 2009.41 p.

6. Duhovsky A.A., Artamonova N.A., Ivanova E.I., Nikiforov I.O. Obyemnaya model Salaminskogo massiva granitov rapakivi i zakonomernosti razmeshcheniya orudeneniya [Three-dimensional model of the Salminsky massif of rapakivi granites and patterns of mineralization distribution]. Otechesvennaya geologiya, 1994, no. 4, pp. 24-32. 
7. Konyshev A.A., Chevychelov V.Yu., Shapovalov Yu.B. Two types of highly differentiated topaz-bearing granites of the Salmi Batholith, Southern Karelia. Geochemistry International, 2020, vol. 58, no. 1, pp. 11-26.

8. Larin A., Beljaev A., Stepanov K. Geological setting of the Salmi batholith. Salmi batholith and Pitkaranta ore field in Soviet Karelia. Eds. I. Haapala, O.T. Ramo, P.T. Salonsaari. Guide 33. Finland, University of Helsinki publ., 1991. pp. 6-7.

9. Amelin Yu.V., Larin A.M., Tucker R.D. Chronology of multiphase emplacement of the Salmi rapakivi graniteanorthosite complex, Baltic Shield: implications for magmatic evolution. Contribution to Mineralogy and Petrology, 1997, vol. 127, no. 4, pp. 353-368.

10. Kraynov S.R., Shvarov Yu.V., Grichuk D.V., Dobrovolsky E.V., Solomin G.A., Borisov M.V., Ryzhenko B.N., Matveeva L.I., Lyalko V.I., Shvets V.M. Metody geokhimicheskogo modelirovaniya i prognozirovaniya $v$ gidrogeologii [Geochemical modeling and forecasting methods in hydrogeology]. Moscow, Nedra Publ., $1988,254 \mathrm{p}$.

11. Bukaty M.B. Reklamno-tekhnicheskoe opisanie programmnogo kompleksa HydroGeo. Nomer gos. registrazii algoritmov i programm vo Vserossiyskom nauchno-tekhnicheskom informatsionnom tsentre (VNTIZ) № 50200500605 [Advertising and technical description of the HydroGeo software package. State number registration of algorithms and programs in the All-Russian Scientific and Technical Information Center (VNTIZ) no. 50200500605] Moscow, VNTIZ Publ., 2005. 7 p

12. Varshal G.M., Kosheeva I.Ya., Sirotkina I.S., Velyuhanova T.K., Inzkirvali L.N., Zamokina N.S. Izuchenie organicheskikh veshchestv poverkhnostnykh vod i ikh vzaimodeystvie s ionami metallov research of organic matters in surface waters and their interaction with metal ions]. Geokhimiya, 1979, no. 4, pp. 598-607.

13. Lipatnikova O.A., Grichuk D.V. Thermodynamic modeling of migration forms of heavy metals in bottom sediments on the example of Ivan'kovskoye reservoir. Moscow University Geology Bulletin 2011, no. 2, pp. 5-59. In Rus.

14. Mantoura R.F.C., Dickson A., Riley S.P. The complexation of metals with humic materials in natural waters. Estuarine and Coastal Marine Science, 1978, vol. 6, pp. 387-408.

15. Krasinzeva V.V., Grichuk D.V., Romanova G.I., Kadukin A.I. Protsessy migratsii i formy nakhozhdeniya khimicheskikh elementov v porovykh vodakh donnykh otlozheniy v Ivankovskom vodokhranilishche [Migration and occurrence forms of chemical elements in pore waters of bottom sediments in Ivankovskoe reservoir]. Geokhimiya, 1982, no. 9, pp. 1342-1354.

16. Varshal G.M., Inzkirveli I.S., Sirotkina I.S., Kolosov I.V., Kosheeva I.Ya. Ob assotsiatsiyakh fulvokislot $\mathrm{v}$ vodnykh rasvorakh [About association of fulvic acids in water solutions]. Geokhimiya, 1975, no. 10, pp. 1581-1585.

17. Yamamoto Y., Kita F., Isono N., Imai S. Impact of competitive $\mathrm{Fe}(\mathrm{III})$ ion on the complexation of humic acid and toxic metal ions. The Japan Society for Analytical Chemistry, 2017, vol. 66, no. 12, pp. 875-883.

18. Elkins K.M., Nelson J. Fluorescence and FT-IR spectroscopic studies of Suwannee river fulvic acid complexation with aluminium, terbium and calcium. Journal of Inorganic Biochemistry, 2001, vol. 87, pp. 81-96.

19. Varshal G.M., Velyukhanova T.K., Kosheeva I.Ya., Dorofeeva V.A., Bauchidze N.S., Kasimova O.G., Makharadze G.A. Izuchenie khimicheskikh form elementov v poverkhnostnykh vodakh [research of chemical forms of elements in surface waters]. Journal of Analytical Chemistry, 1983, no. 38, pp. 1590-1600.

20. Guy R.D., Charabarti C.L. Studies of metal-organic interactions in model systems pertaining to naturals water. Canadian Journal of Chemistry, 1976, vol. 54, no. 16, pp. 2600-2611.
21. Stevenson F.J. Stability constants of $\mathrm{Cu}^{2+}, \mathrm{Pb}^{2+}$ and $\mathrm{Cd}^{2+}$ complexes with humic acids. Soil Science Society of America Journal, 1976, vol. 40, no. 5, pp. 665-672.

22. Varshal G.M., Velyukhanova T.K., Kosheeva I.Ya., Kubrakova I.V., Baranova N.N. Kompleksoobrazovanie blagorodnykh metallov s fulvokislotami prirodnykh vod i geokhimicheskaya rol etikh protsessov [Complexation of noble metals with fulvic acids of natural waters and geochemical role of these processes]. Analiticheskaya khimiya redkikh elementov [Analytical chemistry of rare elements]. Moscow, Nauka Publ., 1988. pp. 112-146.

23. Samadfam M., Niitsu Y., Sato S., Ohashi H. Complexation thermodynamics of $\mathrm{Sr}$ (II) and humic acid. Radiochimica Acta, 1996, vol. 73, pp. 211-216.

24. Lenhart J.J., Cabaniss S.E., MacCarthy P., Honeyman B.D. Uranium(VI) complexation with citric, humic and fulvic acids. Radiochimica Acta, 2000, vol. 88, pp. 345-353.

25. Sonke J.E., Salters V.J.M. Lanthanide-humic substances complexation. I Experimental evidence for a lanthanide contraction effect. Geochimica et Cosmochimica Acta, 2006, vol. 70, pp. 1495-1506.

26. Prikaz ot 13 dekabrya 2016 goda $N 552$ «Ob utverzhdenii normativov kachestva vody vodnykh obyektov rybokhozyaistvennogo znacheniya, $v$ tom chisle normativov predelno dopustimykh kontsentratsiy vrednykh veshchestv $v$ vodakh vodnykh obiektov rybokhozyaistvennogo znacheniya» (s izmeneniyami ot 12 oktyabrya 2018 goda) [Order of December 13, 2016 N 552 «On approval of water quality standards for fishery water bodies, including standards for maximum permissible concentrations of harmful substances in the waters of fishery water bodies» (as amended on October 12, 2018)].

27. Konyshev A.A., Sidkina E.S., Cherkasova E.V., Mironenko M.V., Gridasov A.G., Zhilkina A.V., Bugaev I.A. Migration forms of heavy metals and chemical composition of surface waters in the «Arsenic» shaft area (Pitkäranta Ore District, South Karelia). Geochemistry International, 2020, vol. 58, no. 9, pp. 1068-1074.

28. Kolpakova M.N., Gaskova O.L., Naymushina O.S., Krivonogov S.K. Ebeity lake, Russia: chemical-organic and mineral composition of water and bottom sediments. Bulletin of the Tomsk Polytechnic University. Geo Assets Engineering, 2018, vol. 329, no. 1, pp. 111-123. In Rus.

29. Dinu M.I. Geochemical specifics of the distribution of elements between their forms in lakes in the European part of Russia and Western Siberia. Geochemistry International, 2018, vol. 56, pp. 1036-1045.

30. Lee Y.H. Aluminium speciation in different water types. Ecological Bulletins, 1985, vol. 37, pp. 109-119.

31. Courtign E., Vandecasteele C., Dams R. Speciation of aluminium in surface water. Science of the Total Environment, 1990, vol. 90, pp. 191-202.

32. Kharitonova N.A., Vah E.A. Rare earth elements in surface waters of Priamurye. Features of accumulation and fractination. Bulletin of Tomsk State Universiteta, 2015, vol. 396, pp. 232-244. In Rus.

33. Moermond C.T.A., Tijink J., Van Wezel A.P., Koelmans A.A. Distribution, speciation, and bioavailability of lanthanides in the Rhine-Meuse Estuary, the Netherlands. Environmental Toxicology and Chemistry, 2001, vol. 20, no. 9, pp. 1916-1926.

34. Tang J., Johannesson K.H. Speciation of rare earth elements in natural terrestrial waters: Assessing the role of dissolved organic matter from the modeling approach. Geochimica et Cosmochimica Acta, 2003, vol. 67, no. 13, pp. 2321-2339.

Received: 31 August 2020.

\section{Information about the authors}

Artem A. Konyshev, Cand. Sc., researcher, Vernadsky Institute of Geochemistry and Analytical Chemistry RAS.

Evgeniya S. Sidkina, Cand. Sc., laboratory head, Vernadsky Institute of Geochemistry and Analytical Chemistry RAS. Evgeniya A. Soldatova, Cand. Sc., senior researcher, Vernadsky Institute of Geochemistry and Analytical Chemistry RAS. Denis N. Dogadkin, Cand. Sc., researcher, Vernadsky Institute of Geochemistry and Analytical Chemistry RAS.

Irina N. Gromyak, researcher, Vernadsky Institute of Geochemistry and Analytical Chemistry RAS. 